\title{
Lifetime reproductive success of Greylag Geese Anser anser breeding in south Sweden
}

\author{
Livslång häckningsframgång för grågäss Anser anser häckande $i$ södra Sverige.
}

\author{
LEIF NILSSON \& HAKON KAMPE-PERSSON
}

Abstract

\begin{abstract}
During 1984-2009, 664 adults and 1,944 goslings of Greylag Geese Anser anser were neck-banded in southwest Scania, Sweden. After hatching the area was carefully searched for marked geese, giving more than 100,000 re-sightings. Of those marked as goslings $71 \%$ survived the first year, $52 \%$ the second year, and the oldest bird recorded was 25 years. About $50 \%$ of the survivors were recruited into the breeding population when two to three years old. Of 1,187 geese that survived for at least two years, $25 \%$ produced at least one brood of small young, and $18 \%$ at least one fledged young. The maximum lifetime number of broods with fledged young was nine, but $50 \%$ of the geese known to have bred successfully pro-
\end{abstract}

duced only one brood of fledged young. Ten percent of the geese seen with small goslings produced $47 \%$ of all fledged young. The maximum number of fledged young for a goose of known age was 32 (age 15 years), but two geese marked as adults and followed for 16 and 17 years produced 40 fledglings each.

Leif Nilsson, Department of Biology, Biodiversity, University of Lund, Ecology Building, SE-223 62 Lund, Sweden.E-mail: leif.nilsson@biol.lu.se

Hakon Kampe-Persson, Pulmañi, Glüdas pagasts, Jelgavas novads,LV-3040,kampepersson@hotmail.com

Received 12 March 2018, Accepted 26 April 2018, Editor: Sören Svensson

\section{Introduction}

That only a small proportion of individuals is responsible for the recruitment of young into the next generation has been recorded for a range of avian species, either because the others die before reaching breeding age or do not manage to produce young successfully (Newton 1989). This applies both to smaller shortlived passerines and to larger and long-lived birds such as waterfowl (Cooke et al. 1995, Blums \& Clark 2004, Rees 2006, Black et al. 2014, Weegman et al. 2016). In geese, these aspects have been studied in arctic-breeding geese including the Barnacle Goose Branta leucopsis (Black et al. 2014), Lesser Snow Goose Anser caerulescens caerulescens (Cooke et al. 1995) and Greenland White-fronted Goose Anser albifrons flavirostris (Weegman et al. 2016), but no corresponding studies have been published for geese breeding in temperate regions. During recent decades, the Barnacle Goose has established populations in temperate regions such as the islands in the Baltic Sea and in the Dutch delta. Large scale studies of the species have been undertaken on both Svalbard and Gotland but a detailed study comparing the lifetime reproductive output between the two populations is still lacking (Black et al. 2014).

Information about the breeding performance of individual Greylag Geese Anser anser, a temperate breeding goose species, was collected as a part of a large-scale neck-banding program, originally started by the Nordic Council for Wildlife Research (NKV) to illustrate the migration patterns of different populations in the Nordic countries (Andersson et al. 2001). In addition to the study of migration, intensive studies of different aspects of breeding ecology and population dynamics were carried out in a study area in south-west Scania, south Sweden. Neck banding started in the area in 1984 and continued through 2009 , with observations of neck-banded geese running through 2013. For general information about the breeding performance of Greylag Geese in the study area see Nilsson (2016) and Nilsson \& Persson (1994), and references cited there.

In the present paper, we use the data from this individually marked population of Greylag Geese to calculate the reproductive output for individual geese over their lifetime, measured as the total number of fledged young produced.

\section{Study area}

The current analysis is based on the Greylag Geese that were breeding and neck-banded in south-west Scania, southernmost Sweden (Figure 1), mainly in 
the lakes Yddingen, Fjällfotasjön, Börringesjön and Klosterviken.

During late summer and early autumn, regular searches after neck-banded Greylag Geese were undertaken in a larger area to establish the fledging success for families leaving the breeding area early. Searches were also made in the Foteviken area at the coast (Figure 1), where geese gather on the vast shore meadows in late summer. For a general description of this wider area, see Nilsson \& Persson (1992, 1998).

The Greylag Goose started to breed in the study area during the late 1960 s. When the study started in 1984,120 pairs were breeding. There was a more or less steady increase to a peak of 1,340 pairs in 2004 , after which the population decreased to between 775 and 985 pairs in 2009-2013 (Nilsson 2016).

\section{Methods}

We based our estimates of the breeding success on observations of pairs where at least one in the pair was marked with a neck-band. The families concentrate on certain feeding areas close to the breeding lake where it is easy to obtain an overview of the newly hatched families. The families occur mostly as discrete units easy to follow. The brood rearing areas were checked several times a week after the first appearance of small broods until the last broods fledged.

As most geese breed in arctic and other distant areas the method we used cannot be used for establishing breeding results in these populations, so the productivity has to be established on the basis of age ratio counts and observations of yearlings returning to the wintering areas with their parents (Black et al. 2014, Weegman et al. 2016). Goose families do not break up until late winter or just before spring migration so this method does also work for temperate breeding geese but our method gives more precise results. We can establish the production of both small and fledged young, whereas the other methods only give information of the number of fledged young that survive their first autumn migration.

We caught families of Greylag Geese during early summer, about three weeks before the goslings started to fly, and when the parents still were in the moulting phase and unable to fly, by driving them into nets mounted on the shore meadows at the different lakes and on the golf course at Lake Yddingen (Persson 1994, Andersson et al. 2001). Marking started in 1984 and the last few geese were marked in 2009. Sightings of marked individuals continued to be collected until spring 2013. In total, 664 adults and 1,944 goslings were neck-banded in the study area. These birds yielded a total of 100,500 re-sightings from the local area in south-west Scania and 15,200 re-sightings outside the local area.

Besides a neckband, each bird was fitted with a metal ring from the Swedish ringing office on one of the legs and from 1998 a numbered plastic ring on the other leg. In this way, it was possible to put on a new neckband (with a new code) if the bird was recaptured. As there are some neckband losses, where the bird was not recaptured, there will be a risk of bias when considering long-lived individual's life-time production of young. The values presented here are therefore to be regarded as minima.

In early spring, we searched intensively all potential feeding areas for Greylag Geese to count the number of pairs before they dispersed for nest building and to identify all marked individuals. During the entire spring and early summer, the area was checked at least twice a week for neckbanded individuals, often simultaneous with the pair counts, to establish survival, arrival of the marked geese, pair bonds, and the production of small and fledged young. When the young hatched, intensive surveys of all feeding areas around all lakes were performed at least three times a week. Families with neck-banded adults were checked for fledglings also in the summer. Once a week these searches also extended to staging areas at the coast (Figure 1).

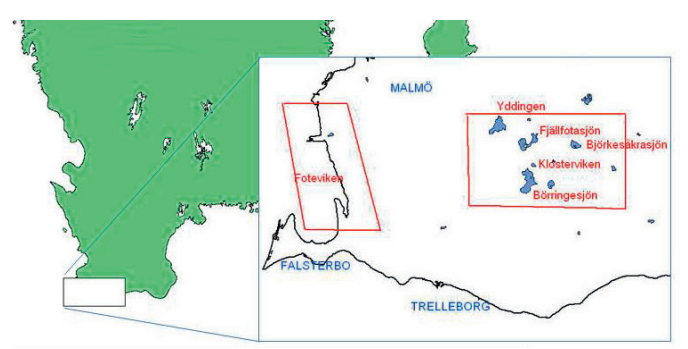

Figure 1. Map of southernmost Sweden showing the geographical position of the study area.

Karta över sydligaste Sverige med undersökningsområdet markerat.

The proportion of the geese attempting to breed is not known as most of the geese placed their nests where it was impossible to check for nests. Instead, we define recruitment into the local breeding population as the first time a bird marked as gosling was seen with small young. A few parents might have been overlooked if they lost all young before reach- 
ing the brood-rearing areas. This risk is considered to be small as the main brood-rearing areas were checked on nearly a daily basis during the main hatching period.

Early brood amalgamation taking place before the family was seen for the first time could normally not be accounted for, as it was usually impossible to identify adopted goslings (Persson 2002). Nine broods that were too large to have been hatched by one female ( $>12$ young) were recorded, and seven of these still numbered more than 12 young at fledging. The geese with apparently amalgamated broods were not included in the calculations of the total production of fledged young.

When calculating the lifetime production of fledged young for geese of known age, we used only geese marked as goslings before the year 1999, which were later recruited into the breeding population, to avoid bias from the very few individuals surviving over the end of the study period. Only geese seen in the study area every year were included in the analysis.

\section{Results}

\section{Survival and recruitment into the breeding population}

Of the 1,944 Greylag Geese neck-banded as goslings, a minimum of $74 \%$ (1438 individuals) survived their first year and 61\% (1187 individuals) survived to at least two years old, i. e. the age of the earliest recruits. The maximum age recorded for a bird marked as gosling included in the analysis here was 18 years, although one bird with an

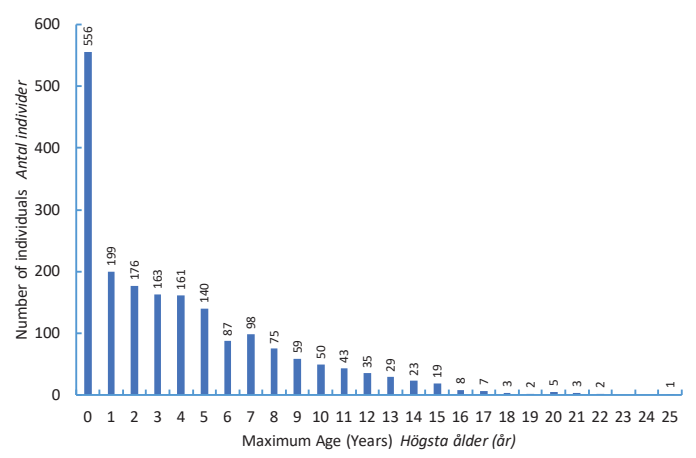

Figure 2. Number of Greylag Geese Anser anser marked as goslings that reached different recorded maximum ages. Antal grågäss märkta som ungar som noterats ha nått olika högsta ålder. incomplete breeding record reached the age of 25 years (Figure 2).

For the 664 Greylag Geese marked as breeding adults, it was not possible to establish their life span as they were at least 2-3 years old at marking. The maximum number of years a bird marked as adult was available for observation in this study was 22 , which gives a minimum age of at least 24-25 years.

Only $15 \%$ of the birds marked as goslings were ever seen with young (Figure 3). Of all birds marked as goslings and surviving for at least two years (1189 individuals), 26\% were at least once found with a brood of small young. About $27 \%$ of these lost their young before fledging and only $18 \%$ of all birds marked as goslings and surviving to the age of at least two years were ever seen with any fledged young.

Of the 309 birds (102 males, 207 females) marked as goslings that were monitored each year until they joined the local breeding population, $18 \%$ (18 males, 38 females) were found to have bred for the first time at age 2 years and about $50 \%$ (33 males, 82 females) when aged 3 years (Figure 4). Some birds did however start breeding much later; the oldest individuals were seen with small young for the first time at eight years of age. There were no differences between the sexes in the age of first breeding. The difference in male and female sample sizes may be partly attributable to a higher rate of neckband losses for males (Persson 2000) but also to male dispersal away from the natal area (Nilsson \& Persson 2001a).

\section{Total production of fledged young}

The maximum number of fledged broods produced by a Greylag Goose of known age was nine, but $50 \%$ of 160 Greylag Geese that bred successfully (i.e. raised young to fledging) only produced one brood of fledged young (Figure 5). The proportion of parents marked as goslings producing fledged young increased by age: $56 \%$ (38 of 88 ) for ages 2-5 years, $74 \%$ (91 of 122) for ages 6-10 years, and $100 \%$ (6 of 6 ) for ages $>10$ years.

Most individuals recruited into the breeding population (seen at least once with small young) had a lifetime production of young that was zero $(32 \%)$ or only between one and nine (54\%) (Figure 6 ). But there are some exceptions, and one Greylag Goose managed to raise 32 young to fledging. The most productive $10 \%$ (15 to 32 young in Figure 7) accounted for $47 \%$ of all fledged young. There is not unexpectedly an effect of age here and the six oldest birds ( $>10$ years old) were all productive 


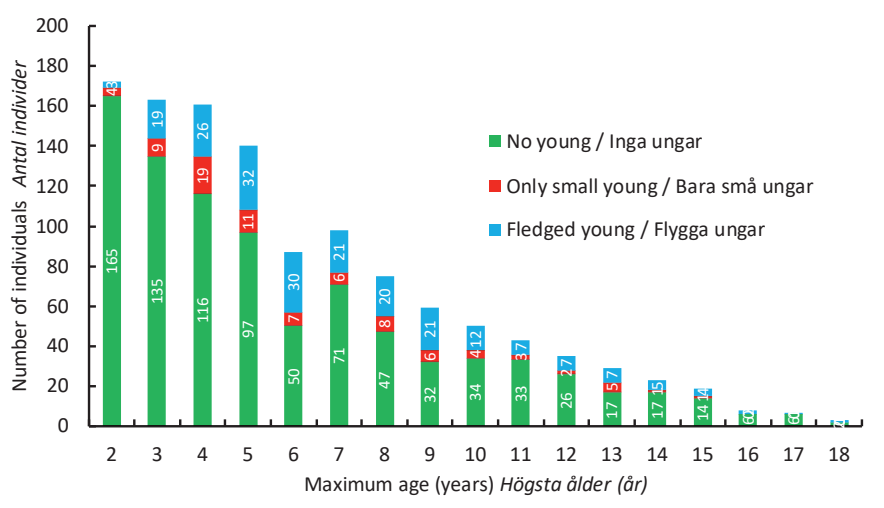

Figure 3. Number of Greylag Geese Anser anser that had been observed with young at least once or never when having reached different maximum ages (at least two years). All had been marked as goslings.

Antal grågäss som setts med unge minst en gång eller aldrig när de nått olika högsta ålder (minst 2 år). Alla hade märkts som ungar.

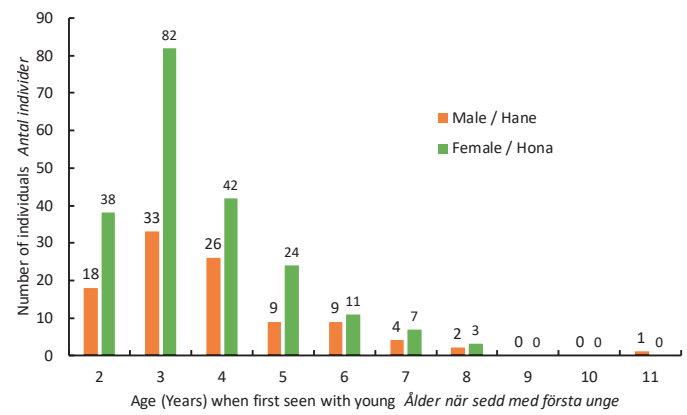

Figure 4. Number of Greylag Geese Anser anser observed with young for the first time at different age, all marked as goslings.

Antal grågäss som setts med ungar för första gången vid olika ålder, alla märkta som ungar.

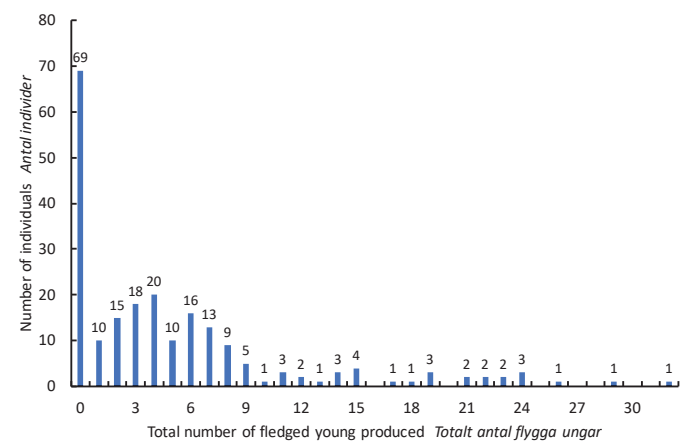

Figure 6. Number of Greylag Geese Anser anser, marked as goslings and recruited into the breeding population (seen with small young), with different lifetime production of fledged young.

Antal grågäss, märkta som ungar och rekryterade in i den häckande populationen (sedda med små ungar), med olika livslång produktion av flygga ungar.

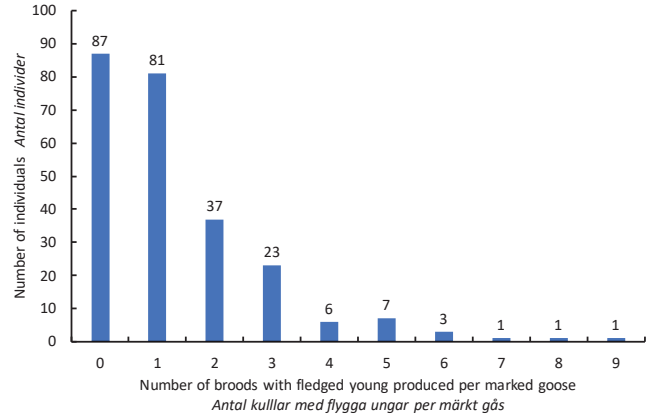

Figure 5. Number of Greylag Geese Anser anser that produced different number of broods with fledged young. All marked as goslings.

Antal grågäss som producerade olika antal kullar med flygga ungar. Alla märkta som ungar.

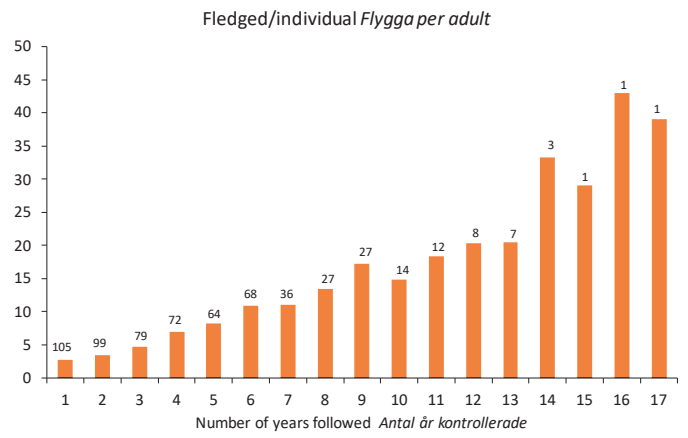

Figure 7. Mean number of fledged young produced by Greylag Geese Anser anser marked as breeding adults (i.e. age not known) in relation to the number of years observed. Values above columns give sample size, number of individuals. Medeltal flygga ungar producerade av grågäss märkta som häckande vuxna (dvs. ålder okänd) $i$ relation till antalet år de kunnat följas. Antalet individ markerat över staplarna. 
producing on average 18 fledged young each. 88 individuals with a maximum life span of $2-5$ years produced an average of 2.7 young, whereas 122 individuals reaching a maximum life of 6-10 years had an average production of fledged young of 6.1.

For Greylag Geese marked as breeding adults, it is not possible to give a true measure of the total production of fledged young, as these birds might have been breeding a number of years before they were marked. For these birds, there was a steady increase in the mean number of fledglings produced with the number of years the birds were under observation (Figure 7). Two successful individuals, followed for 16 and 17 years respectively, each managed to produce at least 40 fledged young. Overall, as for the geese of known age, those marked as breeding adults mostly had a quite low total production of fledged young over the time they could be followed.

\section{Factors affecting the lifetime production of young}

Longevity was the most important factor determining the lifetime production of young. The correlation between lifespan and lifetime production of young was highly significant, even though there was a large spread for parents reaching the same age (Figure 8 , linear regression $\mathrm{r}=0.47, \mathrm{P}<0.001$, $\mathrm{n}=216$ ). In the same way there was a significant correlation between the length of life and the number of breeding attempts (linear regression, $\mathrm{r}=$ $0.57, \mathrm{P}<0.001, \mathrm{n}=186$ ).

In an earlier analysis (Nilsson et al. 1997), the weight at marking, about three weeks before they fledged, was found to have a marked influence on

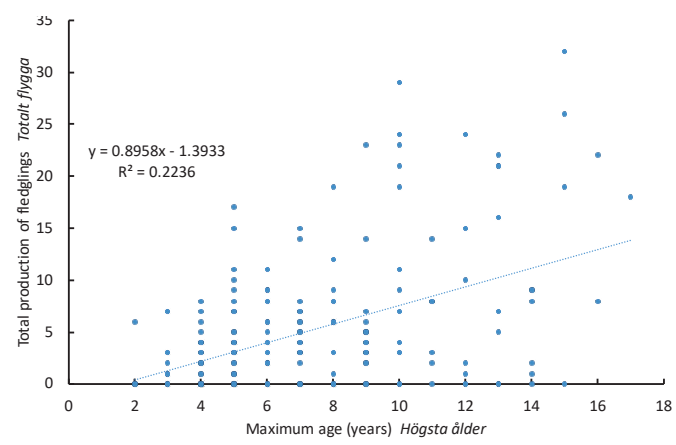

Figure 8. Total production of fledglings in relation to the age of the parent Greylag Geese Anser anser marked as goslings. Linear regression $\mathrm{R}=0.47, \mathrm{P}<0.001, \mathrm{n}=216$.

Total production av flygga ungar $i$ relation till föräldrarnas ålder för grågäss märkta som ungar. Linjär regression $R=0,47, P<0,001, n=216$. the survival and recruitment rate (and age) of the Greylag Geese, with almost all recruits having above median weight at marking. Here, we use the weight close to fledging as a proxy for the condition of the fledgling. We compared these weights at marking with the future total production of fledged young for the same individuals and found a small but significant effect (Figure 9, $\mathrm{R}=0.21, \mathrm{P}<0.01$, $\mathrm{n}=161$ ).

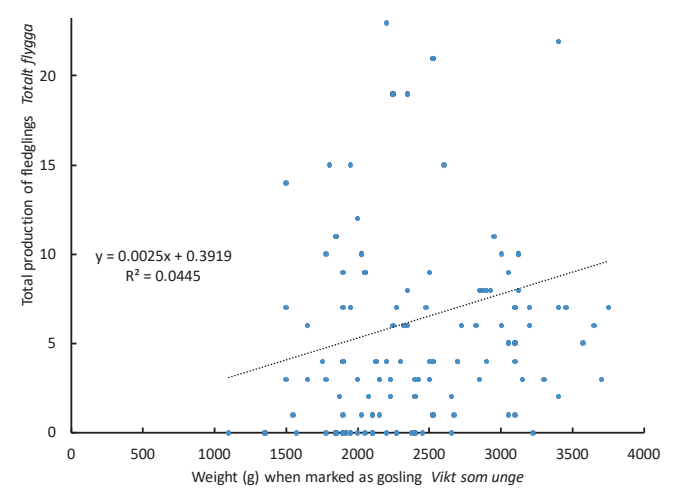

Figure 9. Life-time production of fledged young by Greylag Geese Anser anser marked as goslings in relation to the weight at marking of the parents (as a proxy to their condition). Linear regression $\mathrm{R}=0.21, \mathrm{P}<0.01, \mathrm{n}=161$.

Totalproduktion av flygga ungar för grågäss märkta som ungar $i$ relation till föräldrarnas vikt vid märkning (som mått på deras kondition). Lineär regression $R=0.21, P<0.01, n=161$.

The choice of winter quarter has earlier been found to have an effect on the survival and breeding performance of individual Greylag Geese (Nilsson $\&$ Persson 1996). This effect was also found in the current study. Geese wintering in Doñana in southernmost Spain had a lower breeding output (5.2 young per bird; $\mathrm{n}=86$ ) than geese wintering at Villafáfila in northern Spain $(10.6 ; n=17)$ or in the Dutch delta $(8.6 ; n=94)$.

Experience was found to influence lifetime production of young. $44 \%$ of the Greylag Geese of known age producing fledged young in their first breeding attempt also managed to produce a brood of fledged young in the following year.

\section{Effects on production of young in the second generation}

For 27 Greylag Geese marked as goslings it was possible to establish the total production of their young. No correlation was found between the total production of fledged young of the parents and of their offspring (linear regression $r=0.05$, N.S., $n=27$ ). 


\section{Discussion}

Only a small proportion of the Greylag Geese in the study population in south Sweden managed to produce any fledged young but on the other hand, a small number of the Greylag Geese in the population fledged a larger number of young. The same was the case in the Svalbard Barnacle Goose, where only $17 \%$ of the marked birds arrived in the winter quarters in Scotland with a brood of fledged young (Prop \& de Vries 1993, Black et al. 2014). Unfortunately, there are no similar data available from the temperate breeding populations of the species. A similarly low proportion of Lesser Snow Geese Cooke et al. (1995), and Greenland White-fronted Goose (Weegman et al. 2016) returned to the winter quarters with fledged young. Bewick's Swans Cygnus columbianus bewickii also breed in the arctic and like the geese, many pairs had a low success rate (Rees 2006).

Local conditions and individual characteristics were important for the recruitment of Greylag Geese into the breeding population in south Sweden (Nilsson et al. 1997), heavier goslings recruiting into the breeding population at an earlier age than lighter ones. Young Greylag Geese were first found to recruit at an age of two years, but the vast majority of the recruits was older. Similar results were found for the Greater Snow Geese Anser caerulescens atlantica and Barnacle Geese, which are able to breed at an age of two years but generally recruited into the breeding population at their third or fourth year (Reed et al. 2003, Black et al. 2014). In the studied population of Greenland White-fronted Geese, the recruitment age was generally higher, and varied with the local conditions experienced before the first breeding attempt (Weegman et al. 2016).

In the Greylag Goose breeding in south Sweden, earlier studies established the importance of several factors on the breeding results, such as choice of winter quarters and breeding lake, amount of precipitation in the winter quarters, arrival time in spring, amount of rainfall during the first days after hatching and disease (Nilsson \& Persson 1994, 1996, Persson 1996, Nilsson et al. 1997). Change of mate could also influence the result causing a lower productivity (Nilsson \& Persson 2001b).

Moreover, young with a higher weight at fledging had a higher survival, recruited earlier into the breeding population and had a better breeding output than lighter individuals (Nilsson et al. 1997). In this way, the conditions in the breeding areas (lakes) will influence the reproductive results of the breeding Greylags.
The size of the Greylag Geese at fledging still had a significant but small effect on their lifetime reproductive success (this study). Similarly, larger Barnacle Geese were found to be more successful than smaller individuals (Black et al. 2014). Better breeding results of larger individuals have also been reported for Lesser Snow Geese and Brent Geese Branta bernicla (Ankney \& McInnes 1978, Alisauskas \& Ankney 1990, Sedinger et al. 1995).

In general, factors in the breeding areas had a relatively small effect on the life-time reproduction. Differences in the breeding environment explained about $4.5 \%$ of the variation of the life-time reproduction success of breeding Barnacle Geese in the Svalbard population (Black et al. 2014), whereas $84 \%$ could be attributed to individual characteristics. Similar results were found for the Greenland White-fronted Goose, Weegman et al. (2016).

The choice of winter quarters was also found to have a significant influence on the lifetime reproduction of fledged young of Greylag Geese, individuals wintering in the Dutch delta having a higher lifetime production than those migrating all the way to the former traditional wintering area in southwestern Spain. For those wintering in southwest Spain, there was a strong correlation between the amount of precipitation in autumn in the Guadalquivir Marismas and the breeding output the following season (Persson 1996). Thus, the geese show a similar carry-over effect from the winter conditions to the breeding results as has been established for swans (Nilsson 1979, Brazil 2003, Rees 2006).

Food quality during brood-rearing and predation can have an impact on the breeding output. In an earlier study in the same area, fledging rate was related to the amount of grazed pastures or similar areas that the families had access to during the brood-rearing period (Nilsson et al. 1997). The lowest survival rate was found at the lake lacking such pastures, whereas the highest rates were found at lakes with a rich supply of grazed pastures. During the study period, the supply of grazed pastures in the study area has decreased, as grazing pressure by livestock in many pastures has diminished or ceased.

Geese select nest sites to avoid predators. Islets are preferred when available as hatching success is higher on natural islets than in reed beds (Witkowski 1983). On islets, they are often colonial, with nests as close as one meter (for references, see Kampe-Persson 2002). Another way of avoiding predators is to place the nest in a tree, in an old raptor nest or in a hollow (Kampe-Persson 2007). 
In the early years of our study, the Red Fox Vulpes vulpes was virtually absent from the study area but later; the species re-populated the study area. Besides killing goslings, the foxes restricted the available brood-rearing area by forcing goose families to feed closer to water. On Vega (Norway), White-tailed Eagles Halieatus albicilla killed at least five percent of brooding females on the nest in the early 1990s (Follestad 1994). During the latter part of the study period, White-tailed Eagles spread to the study area. Some geese were killed on their nests and some other geese may have been flushed from the nest by the eagles exposing them to crow predation, which in some years was important (cf. Nilsson et al. 1997).

From what have been said in the last few paragraphs there are indications that the conditions for the production of young was better for the Greylag Geese during the early part of the study. During the study period, the breeding population in the area increased dramatically and Nilsson (2016) found evidence for density-dependent effects. These effects will explain why two birds marked as adults produced at least 40 fledged young each, while none of the birds of known age produced more than 32 fledged young. The latter group of geese was not available until a few years later, when the conditions for the geese may have started to deteriorate.

\section{Acknowledgements}

The Greylag Goose project started as a joint Nordic program supported by the Nordic Council for Wildlife Research (NKV). Over the years, the project was supported by different grants from the Swedish Environmental Protection Agency and the Swedish Sportsmen's Association ("Jägartjugan"). During some years, neck-banding was supported by the Øresund Bridge Company as a part of one of their control programs. The second author was responsible for the catching and marking operations during the first 24 years, with the help of a large number of voluntary "goose-catchers".

\section{References}

Alisauskas, R.T. \& Ankney, C.D. 1990. Body size and fecundity in lesser snow geese. Auk 107: 440-443.

Andersson, Å., Follestad, A., Nilsson, L. \& Persson, H. 2001. Migration patterns of Nordic Greylag Geese Anser anser. Ornis Svecica 11: 19-58.

Ankney , C.D. \& MacInnes, D.C. 1978. Nutrient reserves and reproductive performance of female lesser snow geese. Auk 95: 459-471.
Black, J.M., Prop, J. \& Larsson, K. 2014. The Barnacle Goose. T \& AD Poyser, London.

Blums, P. \& Clark, R.G. 2004. Correlates of lifetime reproductive success in three species of European ducks. Oecologia 140: 61-67.

Brazil, M. 2003.The Whooper Swan. T \& AD Poyser, London.

Cooke, F., Rockwell, R.F. \& Lank, D.B. 1995. The Snow Geese of La Pérouse Bay. Oxford University Press, Oxford, UK.

Follestad, A. 1994. Background for a management plan for geese in Norway. Nina Utredningar 65: 1-78. (Norwegian with English summary).

Kampe-Persson, H. 2002. Anser anser Greylag Goose. BWP Update 4: 181-216.

Kampe-Persson, H. 2007. Tree-nesting - a new trend among Swedish Greylag Geese? Ornis Svecica 17: 187-189. (Swedish with English summary).

Newton, I. 1989. Lifetime Reproduction in Birds. Academic Press, London.

Nilsson, L. 1979. Variation in the production of young in swans wintering in Sweden. Wildfowl 30: 129-134.

Nilsson, L. 2016. Possible density-dependence in an expanding population of Greylag Goose Anser anser in south Sweden. Wildfowl 66: 98-111.

Nilsson, L. \& Persson, H. 1992. Feeding areas and local movement patterns of post-breeding Greylag Geese Anser anser in South Sweden. Ornis Svecica 2: 77-90.

Nilsson, L. \& Persson, H. 1994. Factors affecting the breeding performance of a marked Greylag Goose Anser anser population in south Sweden. Wildfowl 45: 33-48.

Nilsson, L. \& Persson, H. 1996. The influence of the choice of winter quarters on the survival and breeding performance of Greylag Geese (Anser anser). In M. Birkan, J. van Vessem, P. Havet, J. Madsen, B. Trolliet \& M. Moser (eds.), Proceedings of the Anatidae 2000 Conference, Strasbourg, France, 5-9 December 1994. Gibier Faune Sauvage, Game Wildlife 13: 557-571.

Nilsson, L. \& Persson, H. 1998. Field choice of staging Greylag Geese Anser anser in relation to changes in agriculture in South Sweden. Ornis Svecica 8: 27-39.

Nilsson, L. \& Persson, H. 2001a. Natal and breeding dispersal in the Baltic Greylag Goose Anser anser. Wildfowl 52: $21-30$.

Nilsson, L. \& Persson, H. 2001b. Change of mate in a Greylag Goose Anser anser population: effects of timing on reproductive success. Wildfowl 52: 31-40.

Nilsson, L., Persson, H. \& Voslamber, B. 1997. Factors affecting survival of young Greylag Geese and their recruitment into the breeding population. Wildfowl 48: 72-87.

Persson, H. 1994. Neck-banding of Greylag Geese Anser anser in Scania, 1984-1993. Anser 33: 101-106. (Swedish with English summary).

Persson, H. 1996. Survival rates and breeding success in a marked Greylag Goose Anser anser population, wintering in the Guadalquivir Marismas. Revista Florestal 9: 189-199.

Persson, H. 2000. Neck collar retention in a Greylag Goose Anser anser population. Ornis Svecica 10: 155-160.

Persson, H. 2002. Brood amalgamation in the Greylag Goose Anser anser. Ornis Svecica 12: 96-99. (Swedish with English summary).

Pistorius, P.A., Follestad, A., Nilsson, L. \& Taylor, F.E. 2007. 
A demographic comparison of two Nordic populations of Greylag Geese Anser anser. Ibis 149: 553-563.

Prop, J. \& de Vries, J. 1993. Impact of snow and food conditions on the reproductive performance of barnacle geese Branta leucopsis. Ornis Scandinavica 24: 110-121.

Reed,E.T., Gauthier,G. Pradel,R. \& Lebreton,J.D. 2003. Age and environmental conditions affect recruitment in GreaterSnow Geese. Ecology 84: 219-230.

Rees, E. 2006. Bewick's Swan. T \& AD Poyser, London.

Sedinger, J.S., Flint, P.L. \& Lindberg, M.S. 1995. Environmental influence on life-history traits: growth, survival and fecundity in black brant (Branta bernicla). Ecology 76: 2404-2414.

Weegman, M.D., Bearhop, S., Hilton, G.M., Walsh, A. \& Fox, A.D. 2016. Conditions during adulthood affect cohort-specific reproductive success in an Arctic nesting goose population. PeerJ. DOI:10.7717/peerj.2044.

Witkowski, J. 1983. Population studies of the grey-lag goose Anser anser breeding in the Barycz valley, Poland. Acta Ornithologica 19: 179-216.

\section{Sammanfattning}

Det är ett välkänt fenomen att endast en mindre del av individerna $\mathrm{i}$ en fågelpopulation står för rekryteringen av nya häckande individer till populationen (Newton 1989), något som är känt både för kortlivade tättingar och mer långlivade fåglar som olika andfågelarter ( Cooke et al. 1995, Blums \& Clark 2004, Rees 2006, Black et al. 2014, Weegman et al. 2016). Bland gäss har detta fenomen främst studerats för arktiska gäss såsom vitkindad gås (Black et al. 2014), snögås (Cooke et al. 1995) samt grönländsk bläsgås (Weegman et al 2016). Däremot saknas motsvarande undersökningar för gäss häckande i tempererade områden såsom grågås.

Information om häckningsresultat för olika grågåsindivider samlades in inom ramen för ett långvarigt nordiskt grågåsprojekt, vilket startade 1984 (Andersson et al. 2001). Projektet avsåg primärt att studera flyttningsvanorna hos de nordiska grågässen, men i det sydvästsvenska undersökningsområdet genomfördes också en serie studier av olika aspekter på grågåsens häckningsekologi, lokala rörelser och populationsdynamik (se bl.a. Nilsson 2016 samt Nilsson \& Persson 1994).

I föreliggande uppsats utnyttjar vi de insamlade data för att fastställa den totala produktionen av ungar under de olika individernas livstid för grågäss av känd ålder.

\section{Undersökningsområde}

Undersökningarna koncentrerades till SW Skåne (Figur 1). Fångst av grågäss för halsmärkning ägde huvudsakligen rum vid sjöarna Yddingen, Kloster- viken, Fjällfotasjön och Börringesjön. Kontroller efter märkta gäss utfördes inom ett större område. Särskilt under höstarna kontrollerades gässen vid Öresundskusten, speciellt Foteviken, vilket utgör ett viktigt område för grågässen vid denna tid på året.

För en närmare beskrivning av undersökningsområdet hänvisas till tidigare uppsatser (särskilt Nilsson \& Persson 1994).

När undersökningarna startade 1984 häckade totalt 120 par grågäss i området, efter att ha börjat häcka här under senare delen av 1960-talet. Därefter ökade antalet häckande par till en topp på 1340 par 2004, varefter det minskade till mellan 775 och 985 för åren 2009-2013 (Nilsson 2016).

\section{Metodik}

Grågåsfamiljer fångades ungefär tre veckor innan ungarna blev flygga genom att driva dem in i nät som monterats på strandängarna och på golfbanan vid Yddingen (Persson 1994, Andersson et al. 2001). Märkningarna startade 1984 och de sista märktes 2009. Kontrollerna efter märkta i området fortsatte därefter till våren 2013. Området genomsöktes under säsongen regelbundet flera gånger per vecka för att fastställa häckningsresultatet och närvaron av de märkta gässen.

Totalt märktes 664 adulta och 1944 ungar med halsband i det sydvästskånska undersökningsområdet. Märkningarna resulterade i ca 100500 lokala avläsningar, vartill kommer 15200 avläsningar från andra områden.

För att beräkna den totala ungproduktionen för olika gäss har vi endast använt gäss märkta som ungar och sålunda av känd ålder. I våra analyser har vi endast tagit med gäss märkta före 1999 för att inte få en skev åldersfördelning i materialet.

\section{Resultat}

Av de 1944 grågåsungarna överlevde $74 \%$ det första året, medan överlevnaden till två år var $61 \%$. Den äldsta gåsen med komplett serie nådde en ålder av 18 år, men en gås med ofullständig serie nådde en ålder av 25 år (Figur 2). Bland gäss märkta som vuxna häckare (okänd ålder) kunde vi följa en individ under 22 år, vilket innebär att den blev minst 24 år.

Endast $24 \%$ av de gäss som överlevde till två års ålder (1189 individer)sågs åtminstone vid ett tillfälle med en kull små ungar. En del av gässen förlorade ungarna tidigt och andelen som producerade minst en flygg kull var 18\% (Figur 3). 18\% av gässen häckade vid en ålder på två år, medan 50\% 
hade rekryterats vid tre års ålder (Figur 4). Vissa började häcka först betydligt senare, en vid åtta års ålder.

Det högsta antalet kullar med flygga ungar som noterades var nio, men ca $50 \%$ av de grågäss som lyckades med sin häckning producerade endast en flygg kull (Figur 5). Andelen som lyckats ökade inte oväntat med åldern (Figur 6). De flesta gäss som lyckades producera flygga ungar fick ganska få ungar (Figur 7), men en gås producerade 32 flygga ungar. $10 \%$ av gässen stod för $47 \%$ av den samlade ungproduktionen bland de studerade gässen. Gäss som märkts som vuxna (okänd ålder) visade också ett ökat antal flygga ungar med ökat antals studerade häckningssäsonger (Figur 9) och en gås som följdes 17 säsonger producerade under dessa år 40 flygga ungar.

Den totala produktionen av flygga ungar var inte oväntat beroende av förälderns ålder (Figur 10). Som tidigare påvisats (Nilsson et al 1997) var de ungar som vägde mest innan de blev flygga mer framgångsrika i överlevnad och rekrytering till den häckande populationen. De fick också en högre produktion av flygga ungar under sin häckningsperiod. Valet av vinterkvarter påverkade också den totala ungproduktionen (Figur 12). Erfarenhet var också viktig för att lyckas, $44 \%$ av de gäss som producerade en flygg kull ett givet år lyckades även med detta följande år.

\section{Diskussion}

Som framgått av resultatredovisningen bidrog endast en mindre del av grågässen till rekryteringen av nya häckfåglar, vilket också påvisats för andra gäss. Andelen framgångsrika individer var dock något högre hos grågåsen än hos vitkindade gäss från Svalbard och grönländska bläsgäss. Hos båda dessa arter förklarade livslängden en mindre del av den totala produktionen av ungar, medan olika individuella faktorer hade större betydelse liksom fallet hos grågåsen. 